\title{
ANALYSIS OF KANO STATE BUDGET FROM ISLAMIC ECONOMICS PERSPECTIVE 2007-2015
}

\author{
Tasiu Tijjani Sabiu 1*, Muhammad Bako² \\ 1 Northwest University, Kano, Nigeria \\ 2 Northwest University, Kano, Nigeria. \\ *Corresponding author. Email:ttsabiu.economics@nwu.edu.ng \\ Manuscript submitted August 04, 2014; accepted October 13, 2017.
}

\begin{abstract}
Budgeting on conventional ground devises social goals by individualism, self-interest, and misplacement of priorities which creates and widens social inequality. On the other hand, Budgeting from Islamic economics perspective envisages and promotes equity, justice, and equality through mutual consultation and public maslaha and this is achieved by placing the budget in line with the goals of sharia which serves humanity better. The objective of the paper is to critically analyze Kano state budget from 2007 to 2015 based on Maqasid sharia framework. Thus, the paper is a conceptual analysis which relies on journal articles, books, conference proceedings and other relevant materials. The study reveals that the Kano state administration between 2007 to mid2011 incorporate sharia parameters fully into its budget policy and implementation while that of 2011 to mid-2015 partially observe some of the sharia parameters by emphasizing mostly on human capital development and capital project. The paper recommends that since Kano state is a sharia-compliant state and that the future administrations should fully envisage sharia parameters in its budget policies and implementation by placing more emphasis on and proper utilization of sharia supportive institutions or pillars such as Zakat and Hubsi commission, Hisbah board, sharia commission, coupled with productive and sustainable human and capital development projects.
\end{abstract}

Key words: Keywords: Budgeting, Maqasid sharia, Islamic economics.

\section{Introduction}

Modern governments around the globe use budgeting as an integral part of their development planning to estimate their annual expected revenues and expenditures with the sole aim of realizing the objectives of the long-term development plan. Budget in its simplest meaning refers to the sum of money or financial resources allocated for a particular purpose. Technically, it is the estimates of the planned government spending corresponding to the expected revenue generation during a particular period usually a year with the aim of achieving (install mentally) the long-term objectives of the development plan. The expenditure of an Islamic state should comprise three categories as enunciated by Siddiqi (1992). The first category of public spending in an Islamic state includes those which are clearly ordained by the Sharia such as; spending for the protection of religion and territorial 
border of the state, for maintaining law and order, for establishing justice, for enjoying goods and forbidden evils, for spreading the message of Allah, for fulfilling the basic needs of the people, for running the government and for fulfilling the socially obligatory duties in case the private sector is not forthcoming (Siddiqi, 1992). The second category of public spending in Islam is established through ljtihad or jurisprudential analogy which tries to justify a particular activity at the present time with similar or related Shari" ah objective or rule. Spending for research and development, capital formation, etc. are some examples of these spending. While the third category includes spending for the provision of private utilities which are assigned to the state by the people such as clean drinking water, electricity, telecommunications, etc. when the private sector fails to provide due to high capital requirement.

The revenue in an Islamic state usually comes from the income from the public property, from the zakat in some cases and from additional taxes especially at the time of need. This is supposed to be the structure of the budget of any Islamic state, and it is designed to realize the basic objectives of Sharia or Maqasid shari'a. The theory of Maqasid al-shari'a was initially formalized by Imam Al" Ghazali (d. 505 AH) and further elaborated by Ibn Taymiyyah (d. 728 AH) and Al-Shatibi (d. 790 AH) (Abdullah, 2014). According to Imam Al-Ghazali, as cited in Abdullah (2014), there are five objectives (Dharuratul khamsah) which Islamic law aims to achieve. These are the protection of Din (religion), nafs (life), mal (wealth), nasl (progeny) and aql (intellect).

Based on the above structural design of budget from an Islamic point of view, this paper aims to analyze the Kano state (which implemented Sharia as its main guiding principle) budget from Islamic perspectives to see how far has the budget tries to realize the objectives of Sharia.

\section{Literature Review}

The theory of Maqasid Al-Shari'ah as developed by Imam Al-Ghazali and elaborated by Al-Shatibi will be the basis of analysis for this paper. The choice of this theory as the basis of analysis for this study is justified by the fact that the Kano state implemented Sharia as its main guiding principle and therefore all its government policies and activities should be directed toward achieving the objectives of Sharia.

Maqāsid al sharia explains the "wisdom behind rulings," (Auda, 2008). That is the rationale behind any Sharia ruling which comes with commandment, permission or prohibition. For example, the wisdom behind the commandment of alms giving is to remove hardship among the poor people and creates social cohesion. In a nutshell, Maqasid Al-Sharia is the purposes, objectives, goals of Islamic law that leads to the fulfillment of some goods (Maslahah) and the removal of mischief (mafsadah) (Al-Qarafi, d. 1285AH, cited in Auda, 2008).

The theory of Maqasid Al-Sharia as developed by Al-Ghazali stated five objectives which the sharia aims to achieve. These are the protection of religion, life, progeny or family tiers, wealth and intellect (Abdullah, 2014). Now we discuss each of these five objectives briefly to see the variables in the budget that indicates the commitment of the government in each of them.

Protection of Religion is the primary purpose of Sharia. It entails the spreading the message of Allah to all mankind and calling them towards the right path. Spending for enjoying good and forbidden evil such as the institutionalization of Hizbah, ethical reorientation, sponsoring Da' awa activities and Sharia commission can be seen as an effort to protect religion. Protection of life is the rationale behind the sanctification of human life in Islam as can be seen in the ruling that allows killing of anybody who killed a person without any genuine reason (Q2:178). It also entails spending in the 
areas which protect life and improve its healthy condition such as spending on security, health sector, agriculture, etc.

Protection of progeny or family tiers is one of the purposes of revealing the divine law of Islam which protect civic rights of individuals more comprehensive than the doctrine of human right activists in the west. This is because in Islam honor and dignity of a person are sanctified just like his blood and property. Spending in maintaining law and order, education and other related areas can help protect peoples honor and dignity.

Protection of wealth and property is also central to Islam, and it can be achieved by spending in maintaining law and order, for developing commerce and industries, research and development, education, etc. Protection of Intellect is the rationale behind the condemnation of any intoxicant in Islamic law. Intellect is the only distinctive feature of a human being which differentiates him from other animals and also qualifies him to be the vicegerent of Allah on earth. Hence, its protection receives high esteem in Islam. Spending on education, security, law, and order, women and social development, youth empowerment, etc. will ensure the protection of intellectual capabilities of the society.

Based on this framework, this paper will analyze the Kano state budget from 2007 to 2015 to deduce the commitment of the state government toward ensuring the realization of Maqasid alsharia via its budgetary policies.

\section{Methods}

The study used content analysis to analyze the budget by comparing, the objectives of the budget with that of Maqasid al-sharia to measure compatibility and secondly, the percentage allocated to the major variables which indicate one of the five Maqasid al-Sharia to find out the commitment of the state government towards achieving that particular maqasid. For example, as indicated by Auda (2008), preservation of religion, life, progeny, wealth and intellect will ensure the provision of necessities of life.

Therefore, some significant percentage is required in education, sharia commission, health, agriculture, security, law, and order, etc. to ensure the preservation of these five objectives of the sharia. Microsoft Excel 2007 was used to calculate the percentages of capital expenditure allocated to various sectors.

\section{Result and Discussion}

The highest percentage of capital expenditure received by the education sector between 2007 and 2010 is $10.6 \%$ which was in 2009 budget. The sector received $7.4 \%, 5.1 \%$ and $6.5 \%$ in 2007, 2008 and 2010 budgets respectively. This shows the commitment of the state government within that period in providing infrastructural facilities in the education sector which will ensure the provision of qualitative education to the society. Similarly, the highest percentage of capital expenditure received by health, water supply, and agricultural sector within the same period is $6.0 \%, 11.9 \%$, and $13.0 \%$ respectively. While that of works and housing is $25.3 \%$. This also shows the commitment of the then state government in providing the necessities of life. Since provision of necessities of life will ensure the preservation of dharuratul khamsah (i.e., five objectives of sharia) as opined by Al-Shatibi (cited in Abdullah, 2014), the state government within that period, according to the findings, is said to have made an effort towards achieving the objectives of sharia via its budgetary policies.

Although the state government during that period made a commendable effort towards 
preservation and propagation of the religion via Hisbah Board, Sharia commission, Zakkat \& Huebsch and Sharia court. Despite the fact that the administration gives $1 \%$ of the monthly federal statutory grant to the zakat and hubsi commission to be utilized for poverty alleviation which targeted areas like medical assistance, vocational training for the unemployed youth, capital for the widows and periodic assistance to the aged. But the budgetary allocation of capital expenditure to these four Sharia indicators was not significant enough to make these institutions work effectively. The highest percentage of capital expenditure received by these institutions between 2007 and 2010 is $0.27 \%$ for Hisbah Board, $0.42 \%$ for Shari" ah commission and Shari" ah court, $0.86 \%$ for Zakkat and Hubsi.

The allocations of capital expenditure to these necessities of life increase a little bit between 2011 and 2015. These necessities of life are agriculture, water supply, health, education and works, and housing. The highest percentages of capital expenditure received by these sectors between 2011 and 2015 are $8.9 \%, 4.2 \%, 5.4 \%, 10.0 \%$ and $28.5 \%$ respectively. This shows that the state government within that period is more committed to providing the necessities of life than that of 2007 to mid-201 1. Hence, it is in a better position to realize the objectives of Sharia than its predecessor. Similarly, since work and housing received almost one-third of the total budget (28.5\%) in 2014, the government has the opportunity to move from the first step of dharuriyyat (i.e. providing the necessities of life) to hajjiyyat (complementary) and lastly to tahsiniyyat (luxuries) as enunciated by Al Shatibi.

However, the state government between 2011 and 2015 reduces the capital allocation to the major institutions of Sharia in the state. These Sharia icons are the Hisbah board, Shari" ah commission \& Shari" ah courts and Zakkat \& Hubsih. The highest percentage of capital expenditure received by these institutions is $0.06 \%$ for Hisbah board, $0.36 \%$ for Sharia commission \& Sharia courts and $0.84 \%$ for Zakkat and Hubsi. This shows that the state government between 2011 and 2015 is less committed to propagating and preserving the religion as compared to that of 2007 to mid-2011.

\section{Conclusion}

Islam is a complete and total way of life and budget is not an exception. This implies that the structure of the budget of any Islamic state should be designed to realize the basic objectives of Sharia or Maqasid al-sharia because placing the budget in line with the goals of sharia promotes equity, justice, equality and envisages placement of priorities which serves humanity better.

Both administrations of 2007 to mid-2011 and that 2011- mid 2015 have recorded significant success by fulfilling the basic and pressing needs of the people which enable the two administrations to achieve maqasidil sharia in their budget implementation in terms of protecting life, wealth and intellect but the administration 2011-2015 recorded a higher success and credit for even going beyond dharuriyyat to hajjiyat and luxury as well.

However, with respect to protection of religion through sharia supportive institutions like Hisbah, Sharia commission, Zakkat and Hubsi commission, the administration of 2007mid 2011 attaches so much importance to the activities of these institutions because it finds it an indispensable tool for realization of its set objective and this enable the administration to achieve the maqasidil of protecting religion in its budget policy and implementation.

On the hand, the administration of 20112015 neglects these key institutions despite of their importance in terms of promotion, enhancement and development of Islam and cultural values, Initiating and implementing policies that will sanitize business transactions and ensuring orderly relationship among the general public in accordance with the dictates of the Sharia, 
encouraging Muslims to unite in their quest for justice, equality and enjoining one another to do good and avoid evil and poverty alleviation as well. Turning back on this has made the administration of 2011-2015 to fail regarding achieving the maqasidil sharia of protecting and preserving religion.

Since Kano state is sharia-compliant state, Sharia should be its main guiding principle and all its government policies and activities should be geared towards achieving the objectives of Sharia and that the future administrations should fully envisage sharia parameters in its budget policies and implementation by placing more emphasis on and proper utilization of sharia supportive institutions or pillars such as Zakat and Hubs commission, Hisbah board, sharia commission, coupled with productive and sustainable human

and capital development projects.

\section{References}

[1] Abdullah, M. I. (2014), Attainment of maqasid al sharia through Bay Bithamin Ajil Home Financing: Critical Appraisal. Bayero International Journal of Islamic Finance (BIJIF), maiden edition, IIIBF, BUK, Nigeria. Benchmark Publishers. Pp 23-37.

[2] Auda, Y. (2008), Maqasid al-sharia: An Introductory Guide. IIIT. London.

[3] Crane, R. D., (N. D.) Maqasid al-Sharia: A Strategy to Rehabilitate Religion in America. IIIT. London.

[4] Kamali, M. H. (2008) Maqasid Sharia Made Simple, IIIT. London.

[5] KanoStateBudgetSummary2007,2009,2 010,2011,2012,2013 and 2015, Government Printer.

[6] Mamman, L.(2014) "Sharia Implementation in Kano State." International Conference on "the Implementation of Sharia in a Democracy: The Nigerian Experience" the Centre for the Study of Islam and Democracy, Washington D.C. and the Centre for Islamic Legal Studies, ABU Zaria. 